Tack F.M.G., Vanhaesebroeck T., Verloo M.G., Van Rompaey K., Van Ranst E., 2005. Mercury baseline levels in Flemish soils (Belgium). Environmental Pollution 134 (1), 173-179.

The original publication is available at http://www.elsevier.com/

\title{
Mercury baseline levels in Flemish soils (Belgium)
}

Tack Filip M.G. ${ }^{a}$, Vanhaesebroeck Thomas ${ }^{\mathrm{a}}$, Verloo Marc G. ${ }^{\mathrm{a}}$, Van Rompaey Kurt ${ }^{\mathrm{b}}$, Van Ranst Eric ${ }^{\mathrm{b}}$ ${ }^{a}$ Ghent University, Laboratory of Analytical Chemistry and Applied Ecochemistry, Coupure Links 653, B-9000 Gent, Belgium

${ }^{\mathrm{b}}$ Ghent University, Laboratory of Soil Science, Geologisch Instituut, Krijgslaan 281 (S8), B-9000 Gent, Belgium

Corresponding author:

Tack Filip M.G.

Ghent University

Laboratory of Analytical Chemistry and Applied Ecochemistry

Coupure Links 653

B-9000 Gent

Belgium

filip.tack@ugent.be

Tel. 32 (0)9 2645993

Fax. 32(0)9 2646232

Capsule: Increased mercury levels may reflect human activity 


\title{
Mercury baseline levels in Flemish soils (Belgium)
}

\author{
Tack Filip M.G. ${ }^{a^{*}}$, Vanhaesebroeck Thomas ${ }^{\mathrm{a}}$, Verloo Marc G. ${ }^{\mathrm{a}}$, Van Rompaey Kurt ${ }^{\mathrm{b}}$, Van Ranst \\ Eric $^{\mathrm{b}}$ \\ ${ }^{a}$ Ghent University, Laboratory of Analytical Chemistry and Applied Ecochemistry, Coupure Links \\ 653, B-9000 Gent, Belgium \\ ${ }^{\mathrm{b}}$ Ghent University, Laboratory of Soil Science, Geologisch Instituut, Krijgslaan 281 (S8), B-9000 \\ Gent, Belgium
}

\section{Abstract}

It is important to establish contaminant levels that are normally present in soils to provide baseline data for pollution studies. Mercury is a toxic element of concern. This study was aimed at assessing baseline mercury levels in soils in Flanders. In a previous study, mercury contents in soils in OostVlaanderen were found to be significantly above levels reported elsewhere. For the current study, observations were extended over two more provinces, West-Vlaanderen and Antwerpen. Ranges of soil $\mathrm{Hg}$ contents were distinctly higher in the province Oost-Vlaanderen (interquartile range from 0.09 to $0.43 \mathrm{mg} / \mathrm{kg}$ ) than in the other provinces (interquartile ranges from $0.7-0.13$ and $0.7-0.15$ $\mathrm{mg} / \mathrm{kg}$ for West-Vlaanderen and Antwerpen, respectively). The standard threshold method was applied to separate soils containing baseline levels of $\mathrm{Hg}$ from the data. Baseline concentrations for $\mathrm{Hg}$ were characterized by a median of $0.10 \mathrm{mg} \mathrm{Hg} / \mathrm{kg}$ dry soil, an interquartile range from 0.07 to $0.14 \mathrm{mg} / \mathrm{kg}$ and a $90 \%$ percentile value of $0.30 \mathrm{mg} / \mathrm{kg}$. The influence of soil properties such as clay and organic carbon contents, and $\mathrm{pH}$ on baseline $\mathrm{Hg}$ concentrations was not important. Maps of the spatial distribution of $\mathrm{Hg}$ levels showed that the Province Oost-Vlaanderen exhibited zones with systematically higher $\mathrm{Hg}$ soil contents. This may be related to the former presence of many smallscale industries employing mercury in that region.

Keywords: soils, mercury, baseline concentrations, background concentrations, spatial distribution

\section{Introduction}

The metal mercury is known since antiquity. It was known to ancient Chinese and Hindus and was found in Egyptian tombs from around 1500 BC (Hammond, 1975). The huge incident of mass poisoning with $\mathrm{Hg}$ in Minamata Bay in Japan during the fifties has in a dramatic way drawn the attention on the significant hazards associated with its use (ATSDR, 1999).

As a result of natural processes such as volcanic activities and weathering of rock and ores, an estimated amount between 2700 to 6000 metric tons of $\mathrm{Hg}$ is released yearly in the environment. This is about 1.3 to 3 times the rate of release by anthropogenic sources (ATSDR, 1999). An estimated 10000 metric tons of mercury are mined each year, although there is a considerable yearto-year variation (ATSDR, 1999). One third of that amount is used in the chlorine-alkalineindustry. Other uses include application in electronic industry, production of paints, paper industry, pharmaceutical industry, dentistry and agriculture (Sznopek \& Goonan, 2003).

\footnotetext{
* Corresponding author
} 
Mercury is naturally present in soils, although in very low concentrations. Worldwide mercury concentrations in soils range between 0.01 to $0.2 \mathrm{mg} / \mathrm{kg}$ soil (Adriano, 1986). Some concentrations reported for various countries are listed in Table 1.

Due to the long-distance aerial transport of trace elements, true geochemical background concentrations can be difficult to estimate. Geochemical background concentrations should represent natural concentrations, which exclude human influence. Geochemical baselines, in contrast, represent concentrations that are time and area specific. These are not always true background levels (Kabata-Pendias \& Pendias, 1984; Kabata-Pendias et al., 1992).

In a previous contribution (Tack et al., 1997) we estimated baseline concentrations of trace elements for Flanders, Belgium, based on up to 461 observations (156 for $\mathrm{Hg}$ ) in the province OostVlaanderen between the cities of Gent and Antwerpen. The 90\% percentile values for baseline $\mathrm{Hg}$ contents were estimated between 1.1 and $1.9 \mathrm{mg} / \mathrm{kg}$ with a median of $0.17 \mathrm{mg} / \mathrm{kg}$. These levels were significantly higher than those reported elsewhere (Table 1). For this study, additional sampling was performed in other regions in Flanders to investigate whether these relatively high levels are common to different areas in the Flemish region and to improve estimates of baseline Hg-levels for the Flemish region.

\section{Materials and methods}

\section{Compilation of the data}

Mercury baseline concentrations were derived from data obtained from 316 sampling locations in three provinces, West-Vlaanderen $(n=100)$, Oost-Vlaanderen $(n=116)$ and Antwerpen $(n=100)$ in Flanders, Belgium (Figure 1). Soils in Flanders are mostly derived from recent sedimentary parent materials deposited during the Pleistocene or Holocene periods. The geographical regions in the studied area have been described previously (Tack et al., 1997).

Samples were available from several sampling campaigns aimed at assessing baseline trace element concentrations in Flanders. Samples from the province Oost-Vlaanderen were taken during a survey study on soil and plant element contents, conducted by the Laboratory of Applied Analytical Chemistry and Ecochemistry in 1979 and 1980 (Cottenie and Verloo, 1985). Up to 494 points were sampled in an area covering approximately $630 \mathrm{~km}^{2}$ between the cities of Gent and Antwerpen, of which 116 samples were analysed for $\mathrm{Hg}$. Samples from the provinces West-Vlaanderen and Antwerpen were taken during a study in 1998 (Gellinck, 1998; Van Rompaey, 1998) using the same sampling approach as the Oost-Vlaanderen study.

Sampling locations were selected in agricultural fields (61\% of all samples), forest (12\%), pasture $(20 \%)$ or fallow land $(7 \%)$. In all studies, samples were taken from the topsoil $(0-20 \mathrm{~cm})$. Each sample is a composite of between four to eight samples randomly taken within $30 \mathrm{~m}$ around the selected grid point. Samples were stored in polyethylene bags, air-dried upon arrival in the laboratory. They were subsequently sieved through a 2-mm screen and stored in dark and dry conditions at room temperature. 


\section{Analytical procedures}

Soil $\mathrm{pH}$ is based on measuring the $\mathrm{pH}$ of a 1:5 soil: water suspension (Van Ranst et al., 1999). Soil clay and sand contents are based on classical wet and dry seeving techniques and the pipette method (Gee \& Bauder, 1986). For the Oost-Vlaanderen samples, clay contents were in most instances estimated from clay contents determined in neighbouring similar soils (Tack et al., 1997). Organic carbon was estimated using the Walkley \& Black method (Nelson \& Sommers, 1982).

From the more than 300 soil samples available from West-Vlaanderen and Antwerpen, 100 for each province were randomly selected to analyse the $\mathrm{Hg}$ content. Mercury data for the Oost-Vlaanderen soils were taken from the previous studies (Tack et al., 1997; Tack \& Verloo, 1996). To check the quality of these data, 17 samples were re-analysed. A paired t-test revealed no significant difference between the previous and current analyses.

Total soil mercury was analysed with flameless atomic absorption after a specific destruction procedure. In a destruction flask $60 \mathrm{mgV}_{2} \mathrm{O}_{5}$ and $10 \mathrm{ml} \mathrm{65 \%}$ ultrapure $\mathrm{HNO}_{3}$ (Merck, Darmstadt) was added to $0.5 \mathrm{~g}$ of soil. The suspension was then heated at $165^{\circ} \mathrm{C}$ for 30 minutes on a digestor. Then, $15 \mathrm{ml}$ of concentrated $\mathrm{H}_{2} \mathrm{SO}_{4}(18 \mathrm{~mol} / \mathrm{L})$ was added and destruction was continued for one hour. This procedure releases different forms of $\mathrm{Hg}$ in the form of the mercuric cation. For measurement, the suspension was transferred to a glass stoppered glass tube. After addition of $10 \mathrm{ml}$ $10 \% \mathrm{SnCl}_{2}$ solution in $2 \%$ concentrated $\mathrm{H}_{2} \mathrm{SO}_{4}$, the tube was connected to the mercury analyser (Coleman Mercury Analyzer MAS-50B). The solution added reduces all mercury to the metallic form. Air is blown through the suspension that conducts the volatile elemental $\mathrm{Hg}$ through the apparatus such that a transient absorption signal is obtained. The apparatus was calibrated with standards of $0,0.125,0.25,0.5$, and $1 \mu \mathrm{g} \mathrm{Hg}$. A typical calibration curve yielded absorbance values of $0.004,0.053,0.102,0.197$ and 0.377 , respectively. The detection limit $(2 \sigma)$ was approximately $0.03 \mu \mathrm{g} \mathrm{Hg} / \mathrm{kg}$.

The accuracy of the method was verified through analysis of a calcareous loam soil CRM $141 \mathrm{R}$ standard reference sample (Quevauviller et al., 1996). The certified total Hg content of CRM $141 \mathrm{R}$ is $0.25 \pm 0.02 \mathrm{mg} / \mathrm{kg} \mathrm{Hg}$. Triplicate analysis yielded a value of $0.24 \pm 0.05 \mathrm{mg} / \mathrm{kg}$, with both uncertainty intervals reported as the half width of the $95 \%$ confidence interval of the mean.

\section{Data processing}

Statistical analysis was performed using R, an Open Source language and environment for statistical computing and graphics (http://lib.stat.cmu.edu/R/CRAN/) (Ihaka \& Gentleman, 1996). To segregate the population of soil containing baseline $\mathrm{Hg}$ levels from the collected data, probability plots were used to evaluate the presence of multiple populations within the data sets. Multiple populations will form distinct straight-line segments on a probability plot provided each population is normally distributed. Where two populations overlap, an inflection point will form. This point, referred to as the "threshold point" by Fleischhauer \& Korte (1990), represents the separation point between two populations. The threshold was taken objectively as the value that gave the skewness of the resultant background population nearest to 0 as described in Fleischhauer and Korte (1990) and Tobias et al. (1997). The highest values were consecutively removed from the data and the skewness of each resulting population was calculated. The threshold point was identified as the data point for which the resulting population showed the skewness nearest to 0 . Through this method, populations can be identified and segregated from one another for further analysis. Segregation of 
the data will be partial where overlap exists; however, the statistical bias probably will remain small (Fleischhauer and Korte, 1990). Baseline mercury concentration ranges were estimated from the segregated dataset using non-parametric statistics such as the median and percentile values.

Contour maps displaying the spatial distribution of $\mathrm{Hg}$ in each province were produced based on geostatistical analysis using the package GeoR (http://www.est.ufpr.br/geoR/) (Ribeiro \& Diggle, 2001). Spatial interpolation was performed using ordinary kriging. Covariance parameters were estimated by fitting a parametric model to an empirical variogram using ordinary least squares. For other settings, program defaults were used (Ribeiro \& Diggle, 2001).

\section{Results and discussion}

\section{Soil properties and mercury contents}

A statistical summary of the observations grouped by province and for the combined data is provided in Table 2. Soils of West-Vlaanderen are characterised by higher clay and $\mathrm{pH}$ values compared to soils in the other provinces. The soils in Antwerpen tend to be sandy and acidic. The soils of Oost-Vlaanderen have intermediate characteristics. For all data, organic carbon contents ranged from below $1 \%$ to $24 \%$, but typical soils in the Flemish region have organic carbon contents between $1.5-2.5 \%$, corresponding to about $3-5 \%$ organic matter.

Mercury contents ranged from lower than the detection limit $(0.03 \mathrm{mg} / \mathrm{kg})$ to $4.2 \mathrm{mg} / \mathrm{kg}$ dry soil. This is a wide range, well above soil mercury ranges reported for non polluted soils (Table 1). Percentile values show that the area sampled in Oost-Vlaanderen clearly has higher soil Hg-contents than the other provinces. The median for Oost-Vlaanderen, at $1.8 \mathrm{mg} / \mathrm{kg}$, is almost twice that of the other provinces and that for all data. One quarter of the Oost-Vlaanderen soil samples had mercury levels above $0.37 \mathrm{mg} / \mathrm{kg}$.

Figure 2 shows a boxplot of the data, where the difference between Oost-Vlaanderen and the other provinces is very apparent. Values larger than $1 \mathrm{mg} \mathrm{Hg} / \mathrm{kg}$ were not plotted. Many of the data of Oost-Vlaanderen are considered 'outliers' in the boxplot of the whole data, i.e., they extend further than 1.5 times the interquartile range and are plotted as dots in the boxplot of the entire data.

\section{Derivation of baseline values}

Concentrations ranges commonly found in the majority of soils of the region are considered baseline concentrations ranges. To estimate baseline concentration ranges from the data, the "standard threshold method", described by Fleischhauwer \& Korte (1990) and Tobias et al. (1997) was applied. In this approach it is assumed that elemental contents will be distributed according to a lognormal distribution. When a different population is represented in the data, it will show up as a deviation from the log-normal distribution.

The normal probability plot of the mercury contents is shown in Figure 3. Low values deviate from linearity because these were under the detection limit and had all been assigned a value of 0.03 $\mathrm{mg} / \mathrm{kg}$. Two different linear segments revealed the presence of two different populations. High data points were removed until the skew of the distribution became minimal. That point was considered the threshold, delineating the baseline-population from soils from a different population. The 
threshold was located at $\log \mathrm{Hg}=-0.39$, which corresponds to a $\mathrm{Hg}$-level of $0.41 \mathrm{mg} / \mathrm{kg}$. Values higher than 0.41 are therefore assumed not to belong to the population of soils with baseline $\mathrm{Hg}$ levels. Data below the threshold were retained to estimate background $\mathrm{Hg}$ contents in Flemish soils from their statistics.

Percentile values for baseline mercury contents are listed in Table 3 . These values can be used as reference values to determine whether a soil might be contaminated or not. Such an indication of contamination only implies that the total contents are higher than one would normally expect in unpolluted areas. No indications may be inferred about potential hazards that could be associated with the observed element contents.

\section{Correlations with soil properties}

Soil properties are expected to be correlated with baseline contents of metals (Tack et al., 1997). Soil constituents such as clay and organic carbon increase the binding capacity of the soil for metals (Bolt \& Bruggenwert, 1976). They decrease the probability that elements released from weathering of the soil minerals or entering the soil through aerial transport and deposition or other sources will be removed by leaching. Baseline contents of metals will therefore tend to be higher in soils with high contents of clay and/or organic matter. Mobility and retention is also strongly affected by soil $\mathrm{pH}$. Cationic elements tend to be more mobile with decreasing $\mathrm{pH}$, while anionic elements will become mobilised at higher $\mathrm{pH}$ values (Förstner, 1990).

Scatterplots of baseline $\mathrm{Hg}$ contents as a function of soil clay and organic carbon contents and $\mathrm{pH}$ (Figure 4) do not reveal distinct trends, although some observations can be made. Mercury contents in soils with high clay contents and high organic C contents (plots A and B in Figure 4) vary over a wider range than those in soils with lower clay or organic carbon contents. This reflects the metal binding capacity of these soil constituents. Mercury, entering the soil system through aerial transport and deposition or released through weathering of soil minerals, will more likely be retained in soils high in clay or organic matter. Also differences in mineralogy and hence lithogenic $\mathrm{Hg}$ levels between sandy and clayey soils may constitute a factor. With respect to $\mathrm{pH}$, wider ranges in $\mathrm{Hg}$ levels occurred in soils with higher $\mathrm{pH}$-values, reflecting a higher tendency for binding in these soils.

In line with the wide scatter in the data, linear trends between soil properties and mercury contents were mostly not significant (Table 4). Only for organic carbon was there a significant positive correlation with baseline $\mathrm{Hg}$ concentrations. However, only $2.5 \%$ of the total variability in baseline $\mathrm{Hg}$ contents is explained by a linear regression model with organic carbon as predictor variable $(\mathrm{Hg}$ $\left.(\mathrm{mg} / \mathrm{kg})=0.098+0.0110 \mathrm{OC}(\%) ; R^{2}=0.0252, p=0.009\right)$. Thus, the influence of soil properties on $\mathrm{Hg}$ baseline contents overall is, although statistically significant, not very important, in contrast to trends found for trace elements such as $\mathrm{Cd}, \mathrm{Cu}, \mathrm{Pb}$ or $\mathrm{Zn}$ (Tack et al., 1997). While clay and organic carbon contents may be major factors in determining the retention of trace elements that mainly occur in cationic forms (e.g. $\mathrm{Zn}, \mathrm{Cu}, \mathrm{Pb}$ ), the more complex environmental chemistry of $\mathrm{Hg}$ implies that several mechanisms may control $\mathrm{Hg}$ retention. For example, the retention of $\mathrm{Hg}$ in soils is not only caused by valence-type ionic adsorption on organic and inorganic materials. It may also be controlled by formation of covalent bonds with organic compounds or by precipitation as highly insoluble carbonates, phosphates or sulphides (Adriano, 1986; Yaron et al., 1996). 


\section{Spatial distribution of mercury levels}

The spatial distribution of $\mathrm{Hg}$ contents as estimated by kriging, is mapped in Figures 5 to 7 for West-Vlaanderen, Oost-Vlaanderen and Antwerpen, respectively. Contours were plotted with respect to the estimated baseline values. White and light gray correspond to levels below and darker grays to levels above the $90 \%$ percentile values of the estimated baseline contents. These plots may allow to identify areas where systematically higher levels were encountered, but should not be used to draw conclusions on the parcel level because the sampling grid is too coarse.

Two spots with higher levels in West-Vlaanderen (Figure 5) are based on a single measuring point and should therefore be further investigated before conclusions can be drawn. Also for the third, larger area, no readily explanation for the higher levels is available as it concerns a rural area. The sampled area in Oost-Vlaanderen (Figure 6) shows large areas with concentrations above the 90\% percentile value of baseline levels, indicating systematically higher $\mathrm{Hg}$ soil contents in that area. A possible explanation of the markedly increased $\mathrm{Hg}$ levels in the investigated part of the province Oost-Vlaanderen can be found in the former presence of many small-scale industries employing $\mathrm{Hg}$ in that region. The area around the city of Lokeren, for example, was particularly known for the production of felt. In the old processes for the production of felt, mercuric nitrate was used to hydrolyse rabbit fur (ATSDR, 1999). Areas with levels above $1 \mathrm{mg} / \mathrm{kg}$ correspond to urban and industrialised areas around Lokeren, Hamme, and Kruibeke.

Figure 7 shows the map for the province of Antwerpen. Most of the area is below the $90 \%$ percentile of the derived baseline $\mathrm{Hg}$ contents. The south west in particular shows higher contents. It corresponds to a highly industrialised area with non-ferro metallurgical, electro-technical and chemical industry. The area around Antwerpen harbour, another highly industrialised region in the north-west, was not included in the sampling.

In summary, baseline levels estimated from the current data are in line with those reported elsewhere, with a median of 0.102 and a $90 \%$ percentile value of $0.229 \mathrm{mg} \mathrm{Hg} / \mathrm{kg}$ dry soil. Soil $\mathrm{Hg}$ levels in some of the areas sampled in Oost-Vlaanderen appeared significantly affected by human activities.

\section{References}

Adriano, D.C., 1986. Trace elements in the terrestrial environment. Springer-Verlag, New York, NY.

ATSDR, 1999. Toxicological Profile for Mercury. ATSDR/U.S. Public Health Service, Atlanta, GA.

Bolt, G.H., Bruggenwert, M.G.M., 1976. Soil Chemistry. A. Basic Elements. Elsevier, Amsterdam.

Brabo, E.S., Angelica, R.S., Silva, A.P., Faial, K.R.F., Mascarenhas, A.F.S., Santos, E.C.O., Jesus, I.M., Loureiro, E.C.B., 2003. Assessment of Mercury Levels in Soils, Waters, Bottom Sediments and Fishes of Acre State in Brazilian Amazon. Water Air and Soil Pollution 147 (1-4), 61-77.

Chen, M., Ma, L.Q., Harris, W.G., 1999. Baseline Concentrations of 15 Trace Elements in Florida Surface Soils. Journal of Environmental Quality 28 (4), 1173-1181.

Cottenie, A., Verloo, M., 1985. Chemische karakterisatie van bodemverontreiniging. Laboratorium voor Analytische en Agrochemie, RUG, Gent. 
Cox, G.A. and Colvin, G.G. (1996) Evaluation of background metal contents in Ohio soils. CoxColvin \& Associates, Inc., Columbus, Ohio

Curlic, J., Sefcik, P., Vojtas, J., 1995. Preliminary results on background values for some elements in Slovakian soils. In: Proc. Conf. "From soil survey to sustainable farming" Stara lesna.

Fleischhauer, H.L., Korte, N. Formulation of Cleanup Standards for Trace Elements with Probability Plots. Environmental Management 14 (1), 95-105.

Förstner, U., 1993. Metal speciation - general concepts and applications. International Journal of Environmental Analytical Chemistry 51, 5-23.

Gee, G.W., Bauder, J.W., 1986. Particle-size analysis. In: Klute, A. (Eds.), Methods of soil analysis, Part 1. Physical and mineralogical methods. ASA, Madison, Wisconsin, pp. 377-382.

Gellinck, B. (1998) Het verband tussen achtergrondwaarden van zware metalen en bodemkenmerken in de bodems van de provincie West-Vlaanderen. Universiteit Gent, Gent

Hammond, C.R., The elements. In: CRC handbook of Chemistry and Physics. CRC Press, Cleveland, OH, pp. 5-38.

Ihaka, R., Gentleman, R., 1996. R: a language for data analysis and graphics. Journal of Computational and Graphical Statistics 5, 299-314.

Kabata-Pendias, A., Dudka, S., Chlopecka, A., Gawinowska, T., 1992. Background levels and environmental influences on trace metals in soils of the temperate humid zone of Europe. In: Adriano, D.C. (Eds.), Biogeochemistry of trace metals. Lewis Publishers, Boca Raton, pp. 6184.

Kabata-Pendias, A., Pendias, H., 1984. Trace elements in soils and plants. CRC Press, Boca Raton, FL.

Kim, K.H., Kim, S.H., 1999. Heavy Metal Pollution of Agricultural Soils in Central Regions of Korea. Water Air and Soil Pollution 111 (1-4), 109-122.

Li, J., Wu, Y., 1991. Historical changes of soil metal background values in select areas of China. Water Air and Soil Pollution 57-58, 755-761.

Nelson, D.W., Sommers, L.E., 1982. Total carbon, organic carbon, and organic matter. In: Page, A.L., Miller, R.H., Keeney, D.R. (Eds.), Methods of soil analysis, Part 2. Chemical and microbiological properties. ASA, Madison, Wisconsin, pp. 539-579.

Podlesakova, A., Nemecek, J., 1995. Contamination and pollution of soils in the Czech republic. In: Proc. Conf. "From soil survey to sustainable farming". Stara lesna.

Quevauviller, Ph., Muntau, H., Fortunati, U., Vercoutere, K., 1996. The certification of the total contents (mass fractions) of $\mathrm{Cd}, \mathrm{Co}, \mathrm{Cr}, \mathrm{Cu}, \mathrm{Hg}, \mathrm{Mn}, \mathrm{Ni}, \mathrm{Pb}$ and $\mathrm{Zn}$ and the aqua regia soluble contents (mass fractions) of $\mathrm{Cd}, \mathrm{Co}, \mathrm{Cr}, \mathrm{Cu}, \mathrm{Hg}, \mathrm{Mn}, \mathrm{Ni}, \mathrm{Pn}$ and $\mathrm{Zn}$ in a calcareous loam soil CRM 141 R. Office for Official Publications of the European Communities., Luxembourg.

Ribeiro, J.R., Diggle, P.J., 2001. geoR: A package for geostatistical analysis. R-NEWS 1 (2), 15-18.

Sznopek, J.L. and Goonan, T.G., 2000. The materials flow of mercury in the economies of the United States and the world. U.S. Geological Survey Circular 1197, Reston, VA. Available on line at http://greenwood. cr.usgs.gov/pub/circulars/c1197/

Tack, F.M., Verloo, M.G., 1996. Metal contents in stinging nettle (Urtica dioica L.) as affected by soil characteristics. The Science of the Total Environment 192, 31-39.

Tack, F.M.G., Verloo, M.G., Vanmechelen, L., Van Ranst, E., 1997. Baseline concentration levels of trace elements as a function of clay and organic carbon contents in soils in Flanders (Belgium). The Science of the Total Environment 201, 113-123.

Tobías, F.J., Bech, J., Sánchez Algarra, P., 1997. Statistical approach to discriminate background and anthropogenic input of trace elements in soils of Catalonia, Spain. Water, Air, and Soil Pollution 100, 63-78.

Van Ranst, E., Verloo, M., Demeyer, A., Pauwels, J.M., 1999. Manual for the soil chemistry and fertility laboratory. International Training Centre for Post-Graduate Soil Scientists, Gent, Belgium. 
Van Rompaey, K. (1998) Het verband tussen achtergrondwaarden van zware metalen en bodemkenmerken in de bodems van de provincie Antwerpen. Universiteit Gent, Gent

Yaron, B., Calvet, R., Prost, R., 1996. Soil pollution: processes and dynamics. Springer-Verlag, Berlin. 


\section{Figure captions}

Figure 1. Map indicating sampling locations in the three provinces, West-Vlaanderen, OostVlaanderen and Antwerpen from left to right, respectively.

Figure 2. Box -and-whisker plot of the data for each of the Provinces and for all data. Whiskers extend to to the most extreme data point which is no more than 1.5 times the interquartile range from the box. Values higher than $1 \mathrm{mg} / \mathrm{kg}$ were not plotted.

Figure 3. Normal probability plot of the data with indication of the 'threshold' (see text for explanation).

Figure 4. Baseline $\mathrm{Hg}$ contents as a function of soil clay content, organic carbon content and $\mathrm{pH}$.

Figure 5. Spatial distribution of $\mathrm{Hg}$ contents in the province West-Vlaanderen with indication of the sampling points. White indicates $\mathrm{Hg}$ levels below the median of baseline $\mathrm{Hg}$ levels, light gray below the $90 \%$ percentile values of baseline levels. Darker colours represent levels above baseline ranges as indicated by the figure legend. Coordinates, which are expressed in meters (m), are according the Belgian Lambert system.

Figure 6. Spatial distribution of $\mathrm{Hg}$ contents in the province Oost-Vlaanderen with indication of the sampling points. White indicates $\mathrm{Hg}$ levels below the median of baseline $\mathrm{Hg}$ levels, light gray below the $90 \%$ percentile values of baseline levels. Darker colours represent levels above baseline ranges as indicated by the figure legend. Coordinates, which are expressed in meters $(\mathrm{m})$, are according the Belgian Lambert system.

Figure 7. Spatial distribution of $\mathrm{Hg}$ contents in the province Antwerpen with indication of the sampling points. White indicates $\mathrm{Hg}$ levels below the median of baseline $\mathrm{Hg}$ levels, light gray below the $90 \%$ percentile values of baseline levels. Darker colours represent levels above baseline ranges as indicated by the figure legend. Coordinates, which are expressed in meters $(\mathrm{m})$, are according the Belgian Lambert system. 
Table 1. Some soil Hg contents reported in literature

\begin{tabular}{llll}
\hline & & $\mathrm{Hg}(\mathrm{mg} / \mathrm{kg})$ & Reference \\
\hline Brazil & Average & 0.077 & Brabo et al. $(2003)$ \\
China & Background & $0.02-0.03$ & Li \& Wu (1991) \\
Florida & Baseline & $0.0008-0.04$ & Chen et al. (1999) \\
Korea & Unpolluted soils $(\mathrm{n}=109)$ & 0.045 & Kim \& Kim (1999) \\
Ohio, USA & Median & 0.06 & Cox \& Colvin (1996) \\
Slovakia & Median & $0.06-0.13$ & Curlik et al. $(1995)$ \\
Czech republic & Background & $0.12-0.19$ & Podlesakova \& \\
& & & Nemecec (1995) \\
Worldwide & Background & $<0.4$ & Kabata-Pendias \& \\
& & & Pendias (1984) \\
\hline
\end{tabular}


Table 2. Summary statistics of the data

\begin{tabular}{|c|c|c|c|c|c|c|c|}
\hline & $\mathrm{n}$ & Min. & 1st Qu. & Median & Mean & 3rd Qu. & Max \\
\hline \multicolumn{8}{|c|}{ West-Vlaanderen } \\
\hline Hg (mg/kg) & 100 & 0.03 & 0.07 & 0.11 & 0.13 & 0.13 & 1.47 \\
\hline Clay $(\%)$ & 100 & 0.6 & 8.5 & 12.3 & 16.7 & 19.6 & 58.1 \\
\hline Sand $(\%)$ & 100 & 8.3 & 32.8 & 54.8 & 53.6 & 71.1 & 99.5 \\
\hline $\mathrm{OC}(\%)$ & 100 & 0.06 & 1.29 & 1.57 & 2.02 & 2.55 & 6.88 \\
\hline $\mathrm{pH}-\mathrm{H}_{2} \mathrm{O}$ & 100 & 3.71 & 5.92 & 6.5 & 6.58 & 7.49 & 8.73 \\
\hline \multicolumn{8}{|c|}{ Oost-Vlaanderen } \\
\hline $\mathrm{Hg}(\mathrm{mg} / \mathrm{kg})$ & 116 & 0.03 & 0.09 & 0.18 & 0.37 & 0.43 & 3.07 \\
\hline Clay (\%) & 108 & 0.4 & 5.4 & 8.3 & 13.6 & 16.5 & 53.8 \\
\hline Sand $(\%)$ & 108 & 5.7 & 40.5 & 56.9 & 56.8 & 77.3 & 94.7 \\
\hline $\mathrm{OC}(\%)$ & 116 & 0.36 & 1.26 & 1.61 & 2.05 & 2.04 & 10.4 \\
\hline $\mathrm{pH}-\mathrm{H}_{2} \mathrm{O}$ & 116 & 4.3 & 5.54 & 6 & 6.13 & 6.71 & 8.1 \\
\hline \multicolumn{8}{|l|}{ Antwerpen } \\
\hline $\mathrm{Hg}(\mathrm{mg} / \mathrm{kg})$ & 100 & 0.03 & 0.07 & 0.10 & 0.21 & 0.19 & 4.19 \\
\hline Clay (\%) & 100 & 0 & 2 & 3.6 & 4.6 & 5.3 & 30.8 \\
\hline Sand $(\%)$ & 100 & 42.4 & 78.7 & 87.5 & 83.9 & 92.6 & 98.6 \\
\hline $\mathrm{OC}(\%)$ & 100 & 0.52 & 1.52 & 2.11 & 2.61 & 2.71 & 23.81 \\
\hline $\mathrm{pH}-\mathrm{H}_{2} \mathrm{O}$ & 100 & 3.31 & 4.2 & 5.21 & 5.12 & 5.8 & 7.4 \\
\hline \multicolumn{8}{|l|}{ All data } \\
\hline $\mathrm{Hg}(\mathrm{mg} / \mathrm{kg})$ & 316 & 0.03 & 0.07 & 0.12 & 0.24 & 0.22 & 4.19 \\
\hline Clay $(\%)$ & 308 & 0 & 3.7 & 7.5 & 11.7 & 14.0 & 58.1 \\
\hline Sand $(\%)$ & 308 & 5.7 & 45.4 & 70.9 & 64.5 & 86.1 & 99.5 \\
\hline $\mathrm{OC}(\%)$ & 316 & 0.06 & 1.32 & 1.74 & 2.22 & 2.51 & 23.81 \\
\hline $\mathrm{pH}-\mathrm{H}_{2} \mathrm{O}$ & 316 & 3.31 & 5.28 & 5.95 & 5.95 & 6.63 & 8.73 \\
\hline
\end{tabular}


Table 3. Estimates of baseline ranges for mercury $(\mathrm{mg} / \mathrm{kg}$ dry soil) based on the percentile values of the data considered to be baseline values.

\begin{tabular}{lllllll}
\hline Percentile & $5 \%$ & $25 \%$ & $50 \%$ & $75 \%$ & $90 \%$ & $95 \%$ \\
\hline $\mathrm{Hg}(\mathrm{mg} / \mathrm{kg})$ & 0.030 & 0.067 & 0.102 & 0.143 & 0.229 & 0.301 \\
\hline
\end{tabular}


Table 4. Pearson correlations between $\mathrm{Hg}$ contents and some soil properties. Significance at the 5\% level is indicated with "*", at the $1 \%$ level with "**"

\begin{tabular}{llllll}
\hline & $\mathrm{Hg}(\mathrm{mg} / \mathrm{kg})$ & Clay $(\%)$ & Sand $(\%)$ & OC $(\%)$ & $\mathrm{pH}$ \\
\hline $\mathrm{Hg}(\mathrm{mg} / \mathrm{kg})$ & 1.000 & 0.033 & -0.058 & $0.159^{* *}$ & 0.043 \\
Clay $(\%)$ & & 1.000 & $-0.844^{* *}$ & $0.184^{* *}$ & $0.640^{* *}$ \\
Sand (\%) & & & -0.087 & $-0.569^{* *}$ \\
OC (\%) & & & 1.000 & 1.000 & -0.037 \\
$\mathrm{pH}$ & & & & 1.000 \\
\hline
\end{tabular}




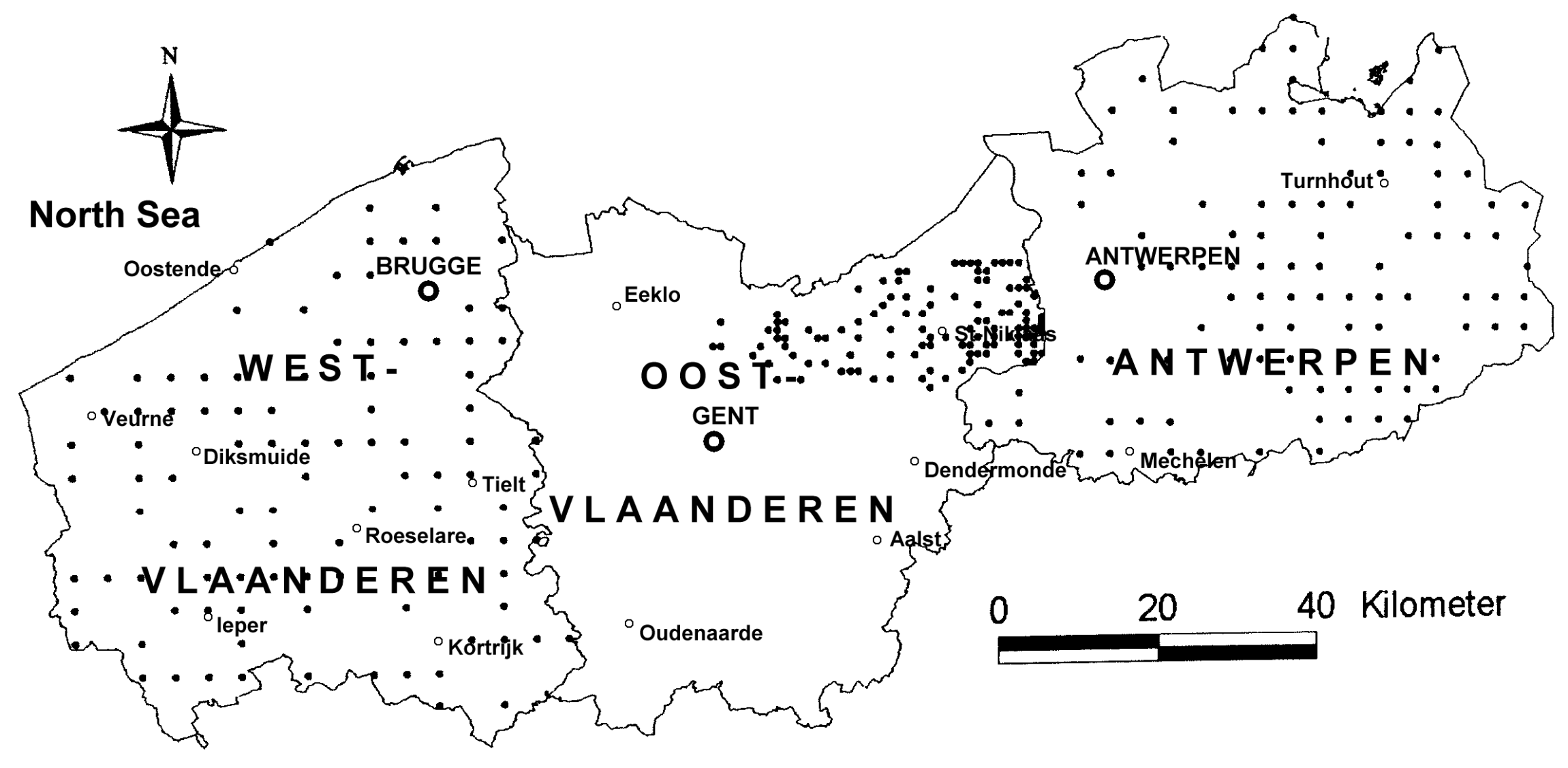




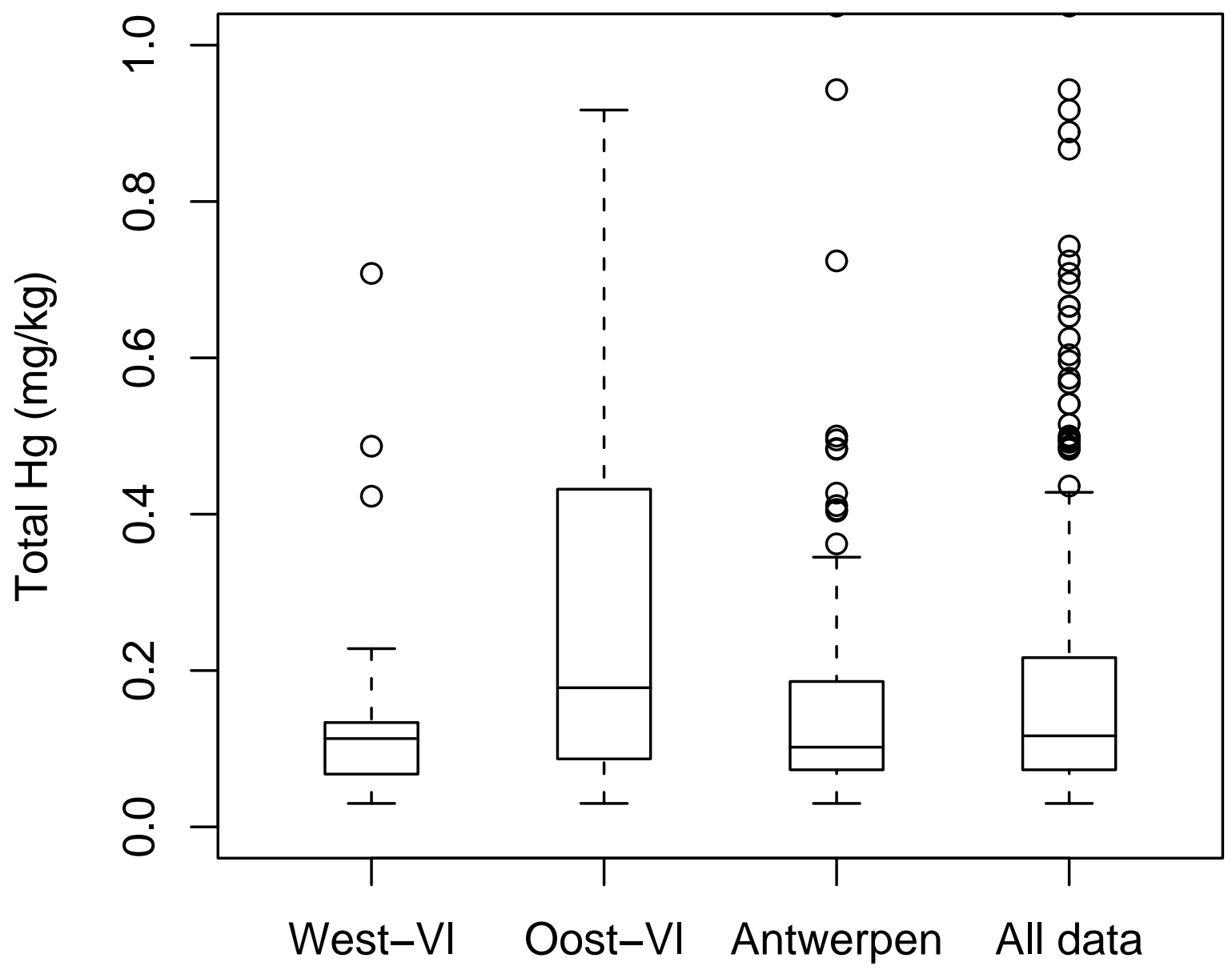

Data group 


\section{Normal Q-Q Plot}

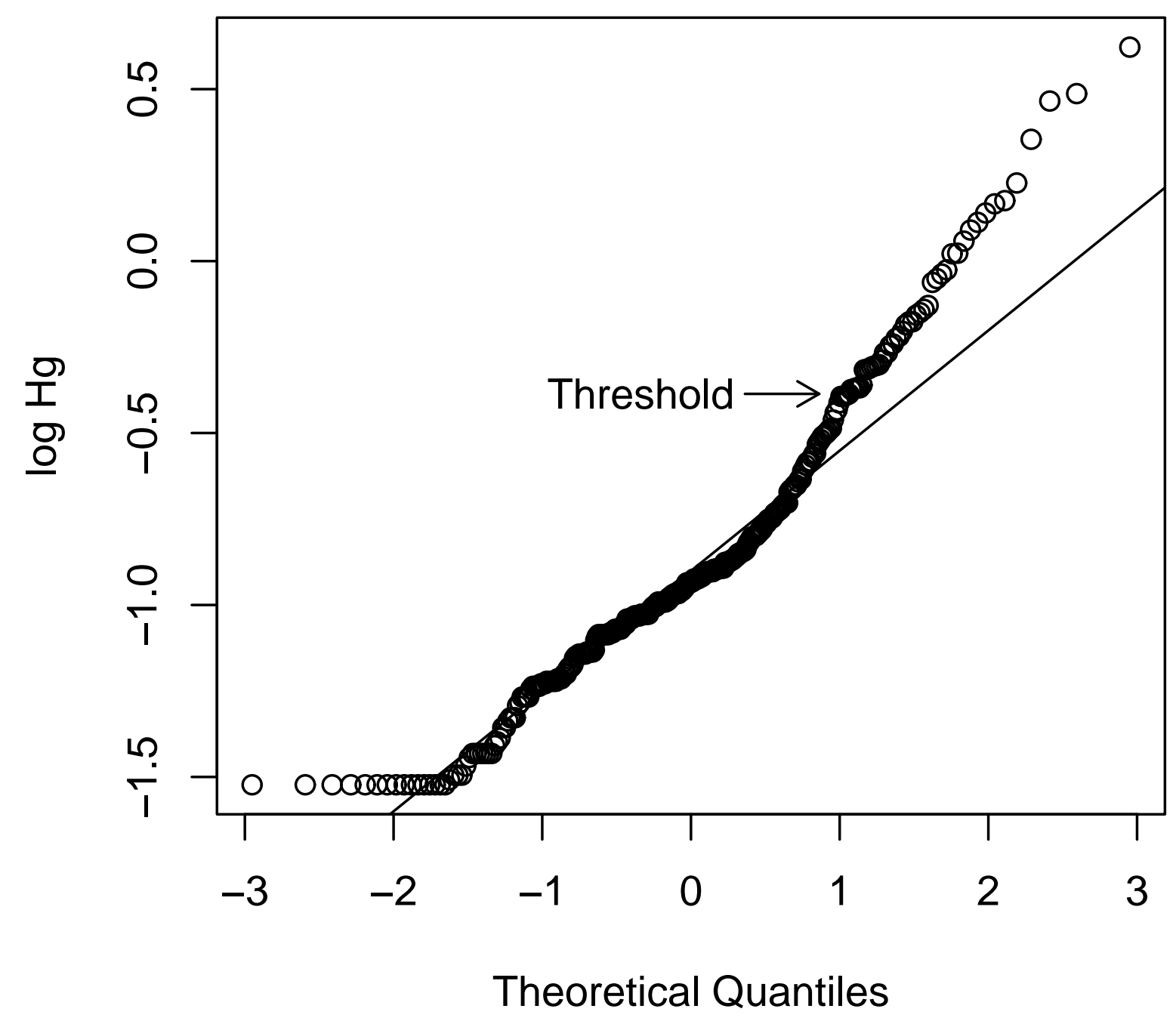



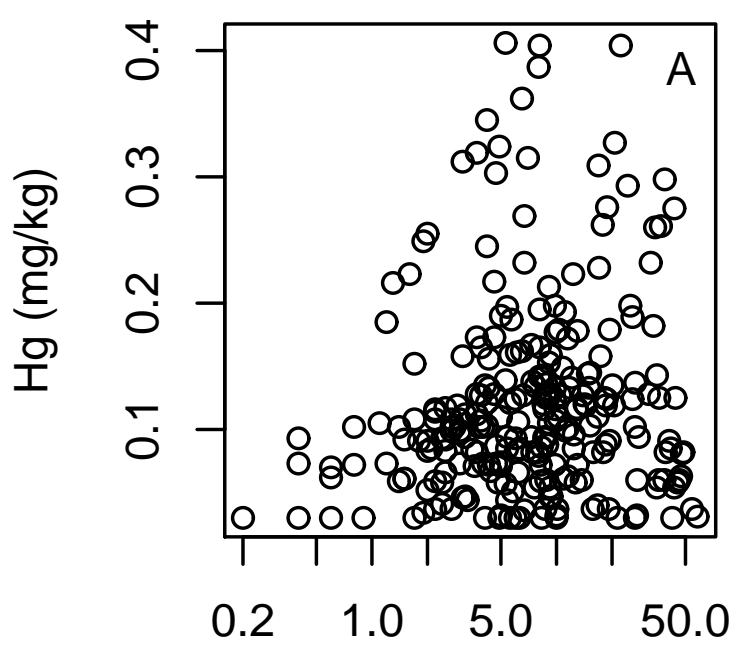

Clay content (\%)

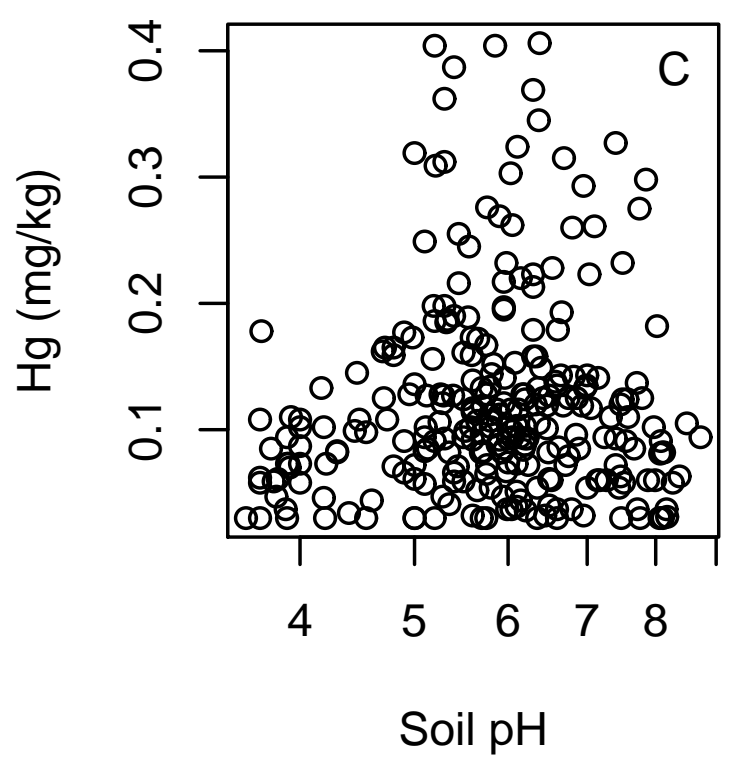

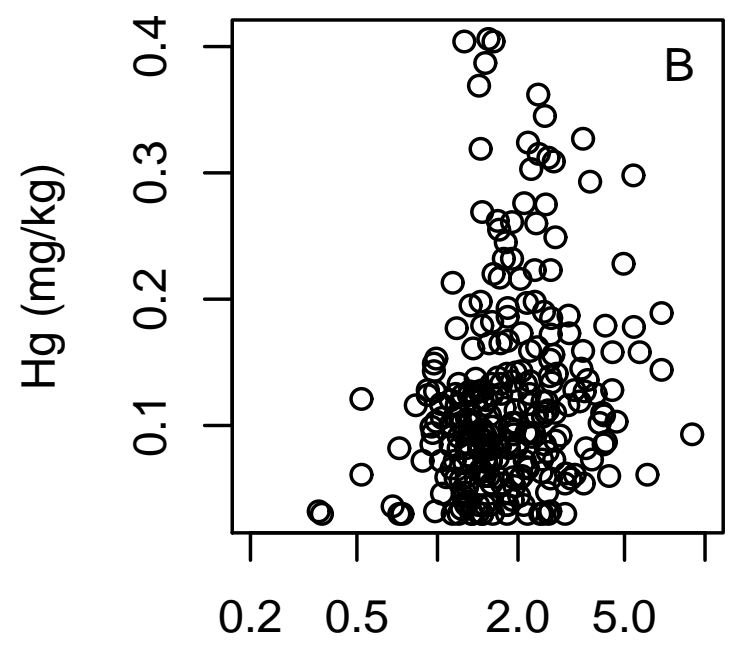

Organic carbon content (\%) 


\section{West-Vlaanderen}

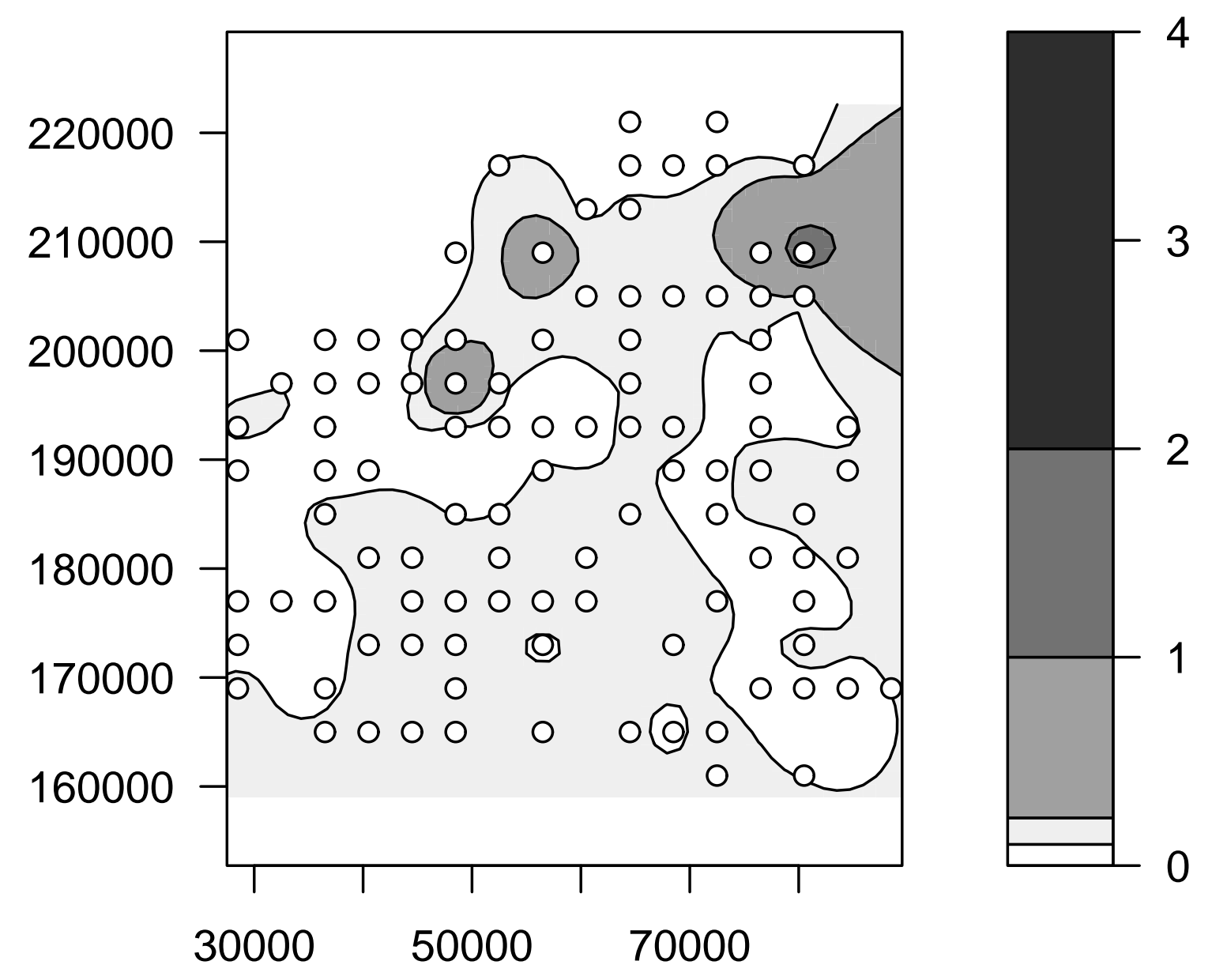




\section{Oost-Vlaanderen}

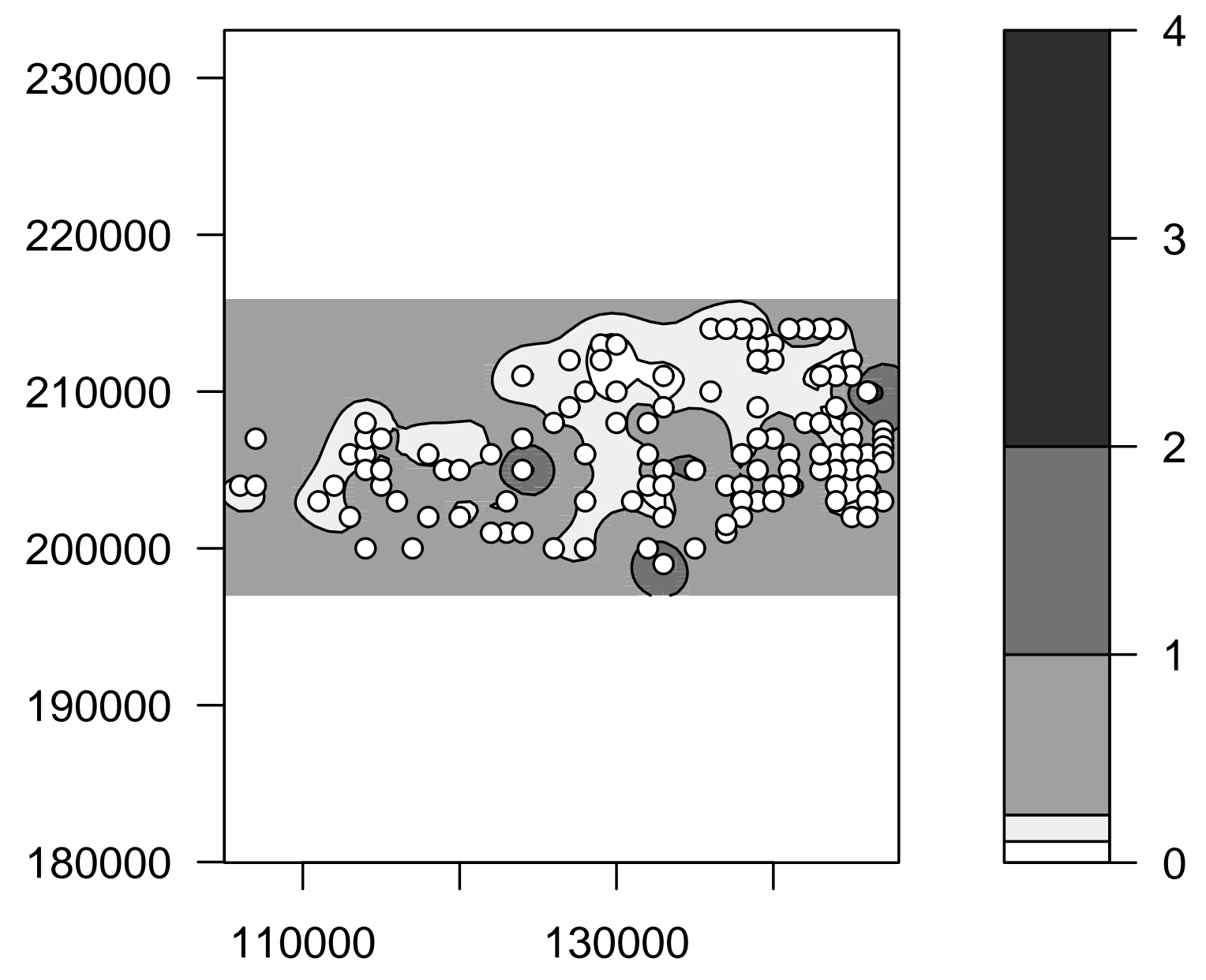




\section{Antwerpen}
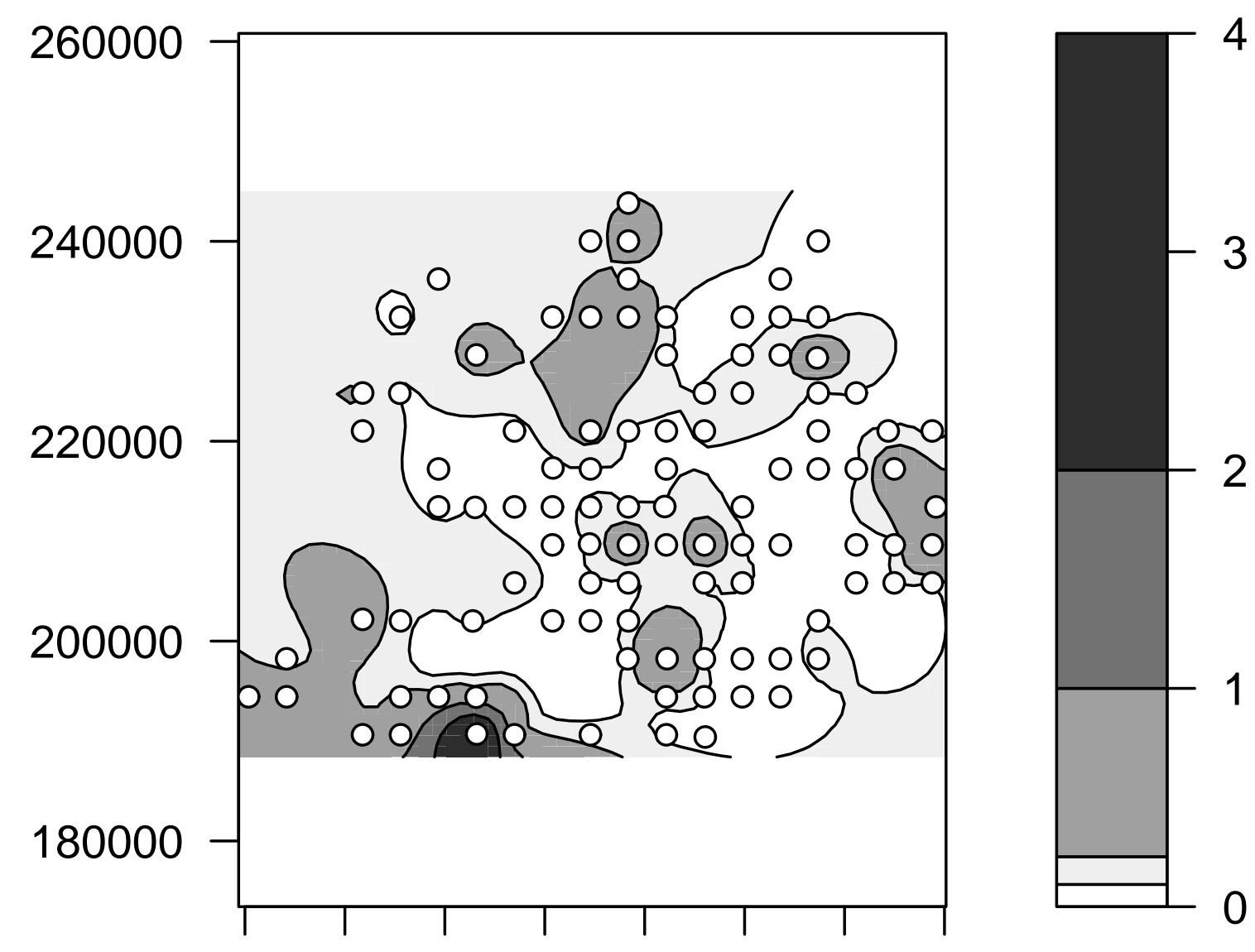

$\begin{array}{llll}140000 & 160000 & 180000 & 200000\end{array}$ 